\title{
Regulation and governance versus criminology: Disciplinary divides, intersections, and opportunities
}

\author{
Paul Almond (1) \\ School of Law, University of Reading, Reading, UK \\ Judith van Erp (D) \\ Faculty of Law, Economics and Governance, Utrecht University, Utrecht, Netherlands
}

\begin{abstract}
This paper seeks to bridge the disciplinary gap between regulation and governance studies, and criminology. Based on a review of theoretical and empirical work on corporate crime, this paper argues that divergent approaches to questions of individual agency, localized variety, and political context, have drawn these two disciplines in different directions. Regulatory governance scholarship has thrived as a discipline, but has also narrowed its focus around these issues. Corporate criminology offers a means of broadening this focus by drawing attention to the normative theorizing behind the regulatory project. At the same time, however, insights drawn from regulatory governance scholarship can prompt corporate criminology to innovate by broadening the scope of its engagement beyond the sphere of traditional criminal justice. The paper argues for the development of a research agenda to sit at their intersection, to engage with the challenges that exist at the interface between criminal and regulatory law.
\end{abstract}

Keywords: corporate crime, criminology, interdisciplinarity, regulation.

\section{Introduction}

Although it is now well established as a discrete "institutional field" (Levi-Faur 2011; Lodge 2016), "regulation and governance" research has been subject to reassessment, challenge, and calls for reflection in recent years. Some of this has come from commentators who wish to assess its development and scope (Lodge 2016; Koop \& Lodge 2017; Picciotto 2017), to appraise its strengths and weaknesses (Black 2002; Almond \& Gray 2017), and to critique the assumptions upon which it is based (Tombs 2015). Many of these criticisms have been prompted by perceived crises of regulation, such as the global financial crisis of 2007-2008, with its evidence of recurrent failures of oversight and risk-management at all levels. Ongoing social challenges, including the implications of Brexit for the European Union and the United Kingdom's (UK) regulatory systems, an American Presidency that challenges regulatory assumptions of rationality and legitimacy, and the threat of global climate change, also provoke an ongoing need for reflection. Our contribution to this process is to examine the relationship between regulation and governance studies and another discipline with an interest in similar questions of ordering within the organizational sphere, namely, the criminology of corporate crime. Despite sharing a great deal in terms of their origins and substantive focus (Braithwaite 2000), these two disciplines have increasingly diverged in recent years. While regulation and governance research has experienced an upsurge in its influence, coming to occupy a position of relative prestige (Lodge 2016), corporate criminology has largely disappeared from the regulation and governance field. This paper identifies the reasons for this, and argues that the opportunities for mutual disciplinary enrichment mean that the criminology-regulation link should be renewed for the future.

Most regulation and governance research pinpoints its emergence as a subfield in the 1980s in response to the growth of a "new regulatory state," the proliferation of new control mechanisms "beyond the state," and the challenges that this posed (Baldwin et al. 1998; Braithwaite 2000; Braithwaite et al. 2007, pp. 2-3; Levi-Faur 2012,

Correspondence: Paul Almond, School of Law, University of Reading, Whiteknights, Reading RG6 7BA, UK. Email: p.j.almond@reading.ac.uk

Accepted for publication 23 May 2018.

C 2018 John Wiley \& Sons Australia, Ltd 
2013; Picciotto 2017). Regulation has been defined as the "intentional intervention in the activities of a target population, where the intervention is typically direct - involving binding standard-setting, monitoring, and sanctioning - and exercised by public-sector actors on the economic activities of private-sector actors" (Koop \& Lodge 2017, p. 105, building on Selznick 1985, p. 363; Black 2002, p. 26). It is generally understood to constitute a narrower undertaking than "governance," the process of "providing, distributing, and regulating," of which regulation constitutes one "large subset" (Braithwaite et al. 2007, p. 3; also Black 2002, p. 6). Such scholarship is characterized by pluralism (Parker 2008), a "decentred" focus (Braithwaite 2000, p. 225; Black 2002), and an emphasis on "governance" as a process of change (Levi-Faur 2012, pp. 7-9), but remains "ecumenical on definitional questions, on what matters substantively, on disciplines and interdisciplinarity, and on epistemology" (Braithwaite et al. 2007, p. 5). From the outset, criminologists were a central component of this interdisciplinary project; as issues of crime, harm, and social conflict were drawn within the scope of the regulatory state (Braithwaite et al. 2007).

Criminology, "the body of knowledge regarding crime as a social phenomenon [including]... processes of making laws, of breaking laws, and of reacting towards the breaking of laws" (Sutherland \& Cressey 1960, p. 3), includes corporate criminology, the study of the "conduct of a corporation, or of employees acting on behalf of a corporation, which is proscribed and punishable by law" (Braithwaite 1984, p. 6), as established via the work of Clinard and Yeager (1980), among others. This is in contrast to the study of white-collar crime, which is individually oriented and typically, but not exclusively, committed by privileged individuals (Shover \& Cullen 2008; van Erp \& Huisman 2017). The influence of criminology on early regulation and governance scholarship was significant. A subject-oriented approach to understanding motivations for offending and non-offending was imported into early regulatory compliance studies by scholars who came to that new discipline from a criminological background, and was particularly visible in their study of the role of subjective factors such as "principled disagreements" and "incompetence" within firms (Kagan \& Scholz 1984), the influence of industry norms and group dynamics (Braithwaite 1984), and the blocking of opportunities to conform to professional values (Braithwaite \& Makkai 1991; Makkai \& Braithwaite 1991). These early criminology-influenced regulatory scholars also positioned the study of enforcement practices as a central concern of regulatory research by examining how complex interactions between enforcers and the regulated, such as negotiation and "bargain and bluff," build trust and virtue, and construct and maintain compliance (Hawkins 1983; Shapiro 1984; Grabosky \& Braithwaite 1986; Haines 1997). Finally, they embedded a strong empirical tradition of studying processes of regulatory policymaking in their social and political contexts (Carson 1982; Calavita \& Pontell 1990). In doing so, this nascent regulation and governance literature drew widely upon "classic" criminology, including the ideas of Sutherland (1949), Matza (1964), Hirschi (1969), Cloward and Ohlin (1962), and Merton (1957), among others.

Although some scholars continue to work at the intersection of regulatory governance and criminology, over time, the visibility of criminology within regulation and governance research has sharply declined. By way of an example, the criminological sources cited above have virtually disappeared from the regulatory literature; only four of the more than 300 articles published in Regulation \& Governance since its inception have cited the work of Edwin Sutherland, the "founding father" (Friedrichs 2015, p. 549) of corporate crime scholarship. This may be attributed to the increasing prevalence of political science and public law methodologies, and the development of a pragmatic approach to the study of social ordering problems, within regulation and governance research (Lacey 2004; Braithwaite et al. 2007; Parker 2008, p. 355). At the same time, corporate criminology has contributed to this process by diversifying (like political science: Almond 1988) into multiple schools of thought along ideological and methodological axes. Similar to distinctions between "critical" versus "professional" or "policy" sociology (Burawoy 2005) and political science (Flinders 2013), or "hard left" and "hard right," in Almond's (1988, pp. 832-835) terms, critical and interpretive ("populist," Shover \& Cullen 2008) corporate criminology can be differentiated from a more empirical and positivist ("mainstream:" Friedrichs 2015, p. 552), "administrative" (Matthews 2017) or "patrician" (Shover \& Cullen 2008) tradition. While the former aims to expose and critique the power relations and hidden assumptions that shape criminal justice, the latter seeks to generate insights grounded in observed practice, rather than critiquing the values underlying that practice. This also maps onto a less uniform distinction between Anglo-American and European corporate criminology traditions (Croall 2015), with the former perhaps more characterized by the polarization discussed above, and the latter characterized by work that sits in "softer," more contextually responsive categories falling between these poles. 
These differences of ideological (between "critical" and "objectivist") and methodological (between "theoretical-interpretive" and "scientific-positivist") approach have left these different traditions occupying "separate tables," working in parallel but in isolation from each other (Almond 1988). Regulation and governance research seems to conform more closely to the objectivist and scientific-positivist tradition than criminology and, indeed, sits at an objectivist and interpretivist "table" of its own (Parker \& Nielsen 2011, pp. 4-8), separate from that of corporate criminology. Differences of approach to issues of individual agency, power, and politics, and the public/private divide, which this paper will outline, lend support to such a conclusion. Such differences also help to explain why consciousness of and engagement with corporate criminology in regulation and governance research has been limited to the critical and interpretivist tradition. It is this strand which has most consciously positioned itself, and been positioned in turn, in opposition to regulation and governance research, an opposition which has, at times, been highly confrontational (e.g. Hawkins 1990; Pearce \& Tombs 1990; Tombs 2015; Lodge 2016). For each side, it has perhaps been useful to define the kind of academic and intellectual endeavor one is not engaged in, by reference to the perceived limitations of an opponent.

These differences have also been reinforced by the need to frame arguments to "fit" with theoretical traditions and publishing conventions in each discipline. Scholars working at the intersection of regulatory research and criminology often have to choose between the language of "crime" and the language of "risk," or between a focus on analytical precision or political dynamics, depending on the disciplinary alignment of their intended publication outlet. These strategies have perhaps created their own self-reinforcing institutional realities, as well as the risk of caricatured, limited perceptions of the value of other disciplines. The "corporate criminology" that is most familiar to scholars working within regulation and governance research is thus unrepresentative of the variety of work conducted on issues of corporate ordering, and is also, by virtue of its oppositionality, necessarily less useful to their work, tending to reject, rather than complement, their approach. Our view, which we substantiate in this paper, is that as a result of this narrow engagement, regulation and governance research has overlooked a diverse and valuable literature. Thus, it has failed to benefit from the insights that this literature provides into corporate crime as a product of individual and organizational motivations, justifications, and conditions.

This paper identifies three core tendencies within regulation and governance scholarship that position it in contrast to much of the corporate criminology literature. First, much regulatory governance scholarship takes a more institutionalist view of the regulatory process than criminology, which places a greater emphasis on questions of individual agency and localized variety. Second, it often engages in a more limited way than criminology with contextual questions of power and politics, assessing the effectiveness of regulatory regimes rather than grounding the choice of these regulatory arrangements in questions of power and ambiguity. And third, regulatory governance scholarship takes a relatively benign view of the phenomena it engages with, seeing (unlike criminology) "governance" beyond the state as an unproblematic means of extending society's capacity to regulate risk. Via a review of both seminal theoretical and recent empirical work on corporate crime, this paper contributes to bringing these two disciplines together, demonstrating the ways in which a criminological approach can broaden the scope of regulation and governance studies, and draw attention to the normative theorizing behind the regulatory project. Criminology, for its part, has tended to overlook the potential of private controls that emerge from civil society, and regulatory insights offer a means of broadening the criminological imagination about societal responses to crimes and deviancy in turn. A research agenda positioned at the intersection of criminological and regulatory governance scholarship, which sought to combine the "ways of seeing" inherent to each discipline, would be able to more comprehensively account for the realities of corporate noncompliance. It would also better account for the punitive and regulatory capacity of criminal sanctions, of prosecutorial agreements and administrative sanctions, and of compliance programs.

\section{Issues of agency and motivation}

Since its formation as a disciplinary area, regulation and governance research has addressed the overarching question of how regulators can best exert influence over the actions of the regulated population, in order to produce desirable outcomes. Much of the regulatory literature is focused primarily on the interactions that occur between "regulated firms" and the multitude of external agencies, organizations, and actors that seek to influence their behavior. While there is great variety in the way that "regulators" are conceived of in this literature (public, private, 
voluntary, market-based, networked, and so on), this top-down view tends to view the organizational entities that engage with it as uniform actors with easily-identifiable motives and interests (Gray \& Silbey 2014). Regulation is often presented as strategic, instrumental, and focused, rather than organic, messy, or contingent (Almond \& Gray 2017, p. 7; although see regulatory "experimentalism" in Overdevest \& Zeitlin 2014). Following a general tendency within the regulatory state to prefer formal regulation over informal relations (Levi-Faur 2013), regulatory research also downplays issues of individual agency and variation. The regulated populations studied tend to be narrowly defined and so the pluralism (Parker 2008) identified in regulation and governance studies generally falls on the "regulator" side of the regulator-regulatee dyad. As one example of this, the majority of empirical and practicebased case studies published in Regulation \& Governance between 2015-2017 focused on the relationship between the "regulatory state," in one form or another, and regulated organizations. They emphasized functional, firm-level explanatory factors (size, type, similarity, ownership status, and geographical distribution, e.g. Fransen \& Conzelmann 2015; Shi \& van Rooij 2016), thereby grounding their analysis at the level of the regulated firm as a whole. Very few studies (nine of 46 published empirical or case studies) engaged explicitly with a broader range of regulatory subjects or micro-level motivations and dynamics (e.g. Etienne 2015; Mills \& Koliba 2015).

There are a number of explanations for this institutional focus. First, regulatory governance primarily conceives of legitimacy as a procedural, rather than a normative, matter (Baldwin 1995; Black 2008), and procedural legitimacy is sought through institutions that structure legality, accountability, and due process (Tyler 2011). Second, regulatory systems are typically concerned with delivering continuity; hence regulatory scholars commonly focus on questions of institutional architecture, such as "How does the regulatory system work?" and "How can it be made to work better?". Corporate criminology, by contrast, is centrally focused on the breakdown of systems of behavior-regulation, as expressed via the causes, occurrence, and consequences of corporate crimes. This lens diverts attention more typically to a focus on disruptions such as disasters and failures, and to questions such as "What went wrong?" and "Why did this happen?". While regulatory scholars do focus on discontinuities, they tend to view such exceptional events as highlighting the tensions within, and limitations of, stable regulatory systems (Haines 1999; Casey \& Lawless 2011; Mills \& Koliba 2015; Hutter \& Lloyd-Bostock 2017), rather than treating them, as criminology often does, as fundamental political challenges to those systems (Calavita \& Pontell 1990; Bradshaw 2015; Tombs 2015). Some scholars who straddle these disciplinary boundaries have contributed work that combines both a grasp of institutional process and influence, and a broader sense of the importance of political context (e.g. Haines 2011b).

A third feature of regulation and governance research that accounts for this institutional focus is its historical links to economic approaches to social policy, viewing regulation as a means of correcting market failures and inefficiencies (Breyer 1982; Veljanovski 2010). Such a focus necessitates a macro-level approach to intervention, as this is where the strategic realignment of incentives can best be performed, but this narrows the focus in terms of the pressures associated with regulated populations. By contrast, Mills and Koliba's (2015) study of the Deepwater Horizon disaster argues that a reliance upon marketized accountability systems, to the exclusion of other decisionmaking frames, created significant gaps within the regulatory framework for offshore safety. Similarly, many criminological studies of organizational compliance demonstrate that variants of economic motivation predominate at the firm level, where issues of material benefit and economic squeeze dictate the likelihood of compliance with the law, in accordance with conceptions of rationalized organizational choice (Simpson \& Rorie 2011; also Paternoster \& Simpson 1993; Thornton et al. 2005, 2009; Rorie 2015). A criminological perspective also introduces a range of motivational factors beyond economic rationality that shape offending behavior and the dynamics of control, and which expand on the notion of a normative "duty to comply" found within the regulatory compliance literature (Gunningham et al. 2005; Kagan et al. 2011; Nielsen \& Parker 2012). At the level of firms themselves, these explanations have included the existence of anomic discrepancies between cultural social goals and the institutional means of firms (Passas 1990; Young 2012; van de Bunt \& van Wingerde 2015), the criminogenic structural necessities of the contemporary capitalist system (Punch 2000; Tombs \& Whyte 2007), and the creation of industry-wide cultures of motivation, opportunity, and control (Williams 2008; Bradshaw 2015; Fligstein \& Roehrkasse 2016).

A final reason for this focus on institutional agency is that regulation and governance studies emphasize the role of pluralized networks and "horizontal relationships" between institutions as the driver of compliance (Braithwaite \& Drahos 2000; Black 2008; Cashore et al. 2011; Levi-Faur 2012). The central dynamic of regulation 
is often viewed as a dyad between large-scale, monolithic (public) regulators and (private) regulatees (Ford 2013; Koop \& Lodge 2017), overlooking other actors (such as employees) who are, in practice, not empowered network members in their own rights (Almond \& Gray 2017, pp. 13-15). This is despite the efforts of seminal regulatory theorists to acknowledge and identify the "many players" and "many selves" that coexist within regulatory settings, and to advocate differential forms of regulatory engagement across these constituencies (Ayres \& Braithwaite 1992, p. 33). This has been a less well-explored component of the "responsive regulation" agenda, as the scale of this concept has been generally limited to mid-range, organizational interactions, and not generally scaled either upwards or downwards (Ford 2013).

The corporate crime literature contributes to our understanding of individual motives for organizational behaviors, particularly within "vertical relationships" between organizations and their individual members - the influence of organizational goals, culture, and hierarchy on the behavior of various actors within organizations (as opposed to the "horizontal relationships" between regulated entities). Why do people commit unlawful activities for the benefit of the collective entities to which they belong? There has been considerable study of the role of individual self-control in causing impulsive, risk-taking behavior on the part of corporate decisionmakers (Reed \& Yeager 1996; Simpson \& Piquero 2002; Piquero \& Moffitt 2014; Schoepfer et al. 2014). Others have pointed to socio-cultural factors, such as gender (Steffensmeier et al. 2013), organizational identity (Klinkhammer 2015), and social networks (Bichler et al. 2015), as well as organizational culture (Simpson \& Piquero 2002). These explanations link to Sutherland's (1949, Ch.15) explanation of individual acts of white-collar criminality as an outcome of "differential associations," or the social learning of definitions of offending as desirable and positive, and of compliance as avoidable and negative. For Sutherland, it is initiation into the corporate setting that exposes individuals to attitudes that legitimate noncompliance; for others, this is more a case of learning "techniques of neutralization" - methods of reconciling one's own beliefs to the contextual norms of organizational offending by downplaying the wrongdoing committed (Stadler \& Benson 2012). In response, enforcement systems must provide external definitions that challenge these learned tendencies, bringing us back to the issue of legitimacy and acceptance of the law. Criminological studies have illustrated the importance of moral education in shaping law-conforming behavior (Jackson et al. 2012), and have asserted the value of communicative legal forms (including the use of criminal sanctions) in restating the moral message that law carries (Almond 2013).

Micro-level regulatory interactions have also been explored in more recent studies that straddle the regulation-criminology divide, and engage with the attitudinal components of regulatory interaction as a driver of offending behavior (Rorie 2015; van Wingerde 2016; Pautz et al. 2017). This suggests that there is no "blindness" to agency within regulation and governance scholarship; rather that attention has tended to focus on the architecture and arrangement of regulatory systems than on the subjective experiences and social interactions that motivate compliance and noncompliance. Regulatory scholarship has begun to explore the agency of a greater range of actors within the regulatory sphere, including "sociological citizens" who mediate and implement regulation (Silbey 2011; Haines 2011a), workers and middle-managers who bear individual responsibilities (Gray 2006), and empowered individuals who share in endogenous legal relationships (Edelman et al. 1999). In doing so, it has been influenced by criminological insights, but has arguably tended to focus on strategic interpersonal interactions, rather than the dynamics of hierarchy, power, and authority within regulated firms, which remains a "lost component" within such studies (Gray \& Silbey 2014). Some important literature has worked toward an integration of individual and organizational drivers of compliance (Simpson et al. 1998; Rorie 2015), illustrating the complexity of these micro-macro connections. Much of the recent empirical research that has engaged with the long-term formation of business cultures that facilitate law breaking has been published in criminological or socio-legal outlets (Bradshaw 2015; Klinkhammer 2015; Rorie et al. 2015; van Wingerde 2016), and offers an underexplored source of insight into the contextual underpinnings of the regulatory sphere.

At the same time, corporate criminology can draw insights into organizational offending from regulation and governance research. The first is to grasp a clearer understanding of the dynamics and risks associated with the adoption of governance-based strategies within criminal settings. Regulation and governance research has devoted a great deal of attention to the limits and trade-offs that such processes involve when left to operate unchecked, not least in the creation (and offsetting) of counterproductive dynamics of diffusion, capture, and bounded rationality (Ford 2010; Mills \& Koliba 2015). As criminal justice systems embrace modes of risk governance (Garland 1997; Braithwaite 2000), a more sophisticated grasp of what "regulation" can achieve, and what it cannot, is needed 
(Haines 2011b). The second point relates to the value of specificity, particularity, and context in seeking to explain corporate offending. Regulation and governance research has provided many nuanced, detailed, and contextspecific accounts of corporate rule breaking. Corporate criminology, however, has increasingly adopted the disciplinary tendency to universalize individualistic and rationalistic explanatory factors across context-sensitive areas of offending (from drug-related, juvenile, and street crime, to corporate and white-collar crime) in pursuit of a scientific "truth" about human behavior. This leads to an emphasis upon individual risk factors, life-course trajectories, and the internal capacities of those within organizations (Simpson \& Piquero 2002; Piquero \& Moffitt 2014; Schoepfer et al. 2014). This also reflects the growing divide between positivist and critical corporate criminologists, and may indicate some desperation on the part of the former to "fit in" to the disciplinary mainstream and signal the maturation of their field and methods. Further, a risk of individualistic accounts is that the unique opportunities for generating, hiding, and spending illegal profit provided by the corporate setting are downplayed.

The third learning point for criminology is in developing a more nuanced understanding of the relationship between the causes of, and possible responses to, corporate wrongdoing. As a discipline, criminology offers an insight into a range of motivations beyond those associated with economic rationality, and has begun to make a more sophisticated contribution to debates around corporate deterrence, stressing the relative merits of prevention and cooperative education, the need for consistent engagement, and the upsides of administrative sanctioning (e.g. Simpson et al. 2014). Critical corporate criminology, on the other hand, remains centrally focused on a model of response that is grounded in the deterrence of calculated, rational offending (Tombs \& Whyte 2007, 2015). This school of corporate criminology is arguably the only branch of criminology to argue that a punitive strategy of criminalization and deterrence-based sanctioning is a good thing (Haines \& Hall 2004, pp. 269-270). It does not share the more optimistic view of administrative sanctions and alternatives to prosecution held within regulation and governance research, and within other branches of criminology, including more positivist strands of corporate criminology. Indeed, ironically, it also tends to be skeptical about the value of state-imposed punishment as a means of crime control in general. As will be argued, such options present many opportunities; they are based on and responsive to the broader understanding of motives and agency that scholars of corporate criminology, broadly defined, are interested in generating.

\section{The role of power and politics}

Just as there is a divergence between the approaches taken by corporate criminology and regulation and governance studies to issues of agency, there is also a divergence in how they treat issues of power, definition, and politics. In large part, this latter divergence is a product of the same epistemological and methodological differences that account for the former. Corporate criminology is the study of the role of elite actors in wrongdoing, meaning that a special interest is taken in harms emerging from the intersection of economic and political power. While regulatory governance scholars explain how regulatory arrangements function in their political, institutional, economic, and social contexts, critical corporate criminology in particular has been distinguished by its aims to make the "crimes of the powerful" visible (Pearce 1976; Barak 2015). It does this by categorizing them as crimes, drawing attention to their otherwise invisible victims and harmful consequences, explaining the differences between corporate crime and "street crime" (in terms of public condemnation and enforcement), and showing how corporations avoid criminalization and define the law so as to permit profit maximization. These social and legal reactions are constructed via the social and economic power of networks of business leaders, corporations, political elites, regulators, and financial and private regulatory actors (such as auditing and accounting firms; Haines 2014). These power relations are sometimes structurally embedded within the political economy and sometimes situational and circumstantial in nature. As such, corporate crime can be a product of either overt and systemic corruption (Friedrichs 2015), or indirect collusion and influence within corporate-political relations (Haines 2014), as in the case of campaign financing and "revolving door" relationships leading to lenient enforcement (Ramirez 2016).

\subsection{Ambiguities of scope and definition}

A pioneering contributor to the study of corporate and white-collar crime (and one often overlooked in favor of Sutherland) was the Dutch criminologist and sociologist Willem Bonger (Braithwaite 1984; Hebberecht 2015). 
Bonger (1916) identified the opportunities available to the bourgeois class to commit undetected frauds, thus underpinning Sutherland's later work. The capacity to avoid detection means that corporate and white-collar crimes remain more socially ambiguous than most other offences, particularly in terms of whether they are labeled as "crimes." Measuring the extent of corporate and white-collar crime according to legal definitions and official sources (conviction rates) achieves greater precision and objectivity, but in doing so, trades off validity for reliability, by focusing attention onto prevalent but trivial offending rather than the serious harms inflicted by elites (Shapiro 1984; Benson et al. 2016; Pontell 2016). Many corporate harms are not formally criminalized, and are instead defined as liability conflicts, tortious wrongs, or simply as "undesirable." Sutherland's (1949) definition included offences that were not legally criminalized, and so provided a more valid reflection of these social harms and the power dimensions underlying criminalization (Geis 2016), but introduced some ambiguity (Tappan 1947).

These definitional ambiguities have severe methodological consequences. First, positivist criminological studies relying on official datasets may grossly underestimate the extent of corporate crime, as most instances remain undetected or unprosecuted. This can mean that explanations of the individual characteristics of offenders may focus on particular populations (such as the middle-class: Weisburd et al. 1991; Shapiro 1984) and invalidly overlook other groups and issues. Problems also exist for empirical criminological scholars in gaining access to data, particularly within corporations (a "criminology" affiliation can deter data sources), and researchers may run the risk of liability claims. This was the reason why the first edition of Sutherland's (1949) inventory of the crimes of major American corporations was anonymized, and why certain academic publishers remain unwilling to publish research findings in which corporate offenders can be identified. Third, definitional ambiguity may translate into ambiguous findings and limit the ability to draw unqualified conclusions. In particular, Rorie et al. (2018) argue that meta-analysis may be unsuited to corporate crime research, as differences in conceptualizing the dependent variable prevent systematic aggregation of findings. This not only disadvantages corporate crime scholarship in the establishment and testing of theory (in comparison to less ambiguous areas of social life), but also hinders the development of criminal policy, as this increasingly seeks to be informed by systematic evidence (Rorie et al. 2018).

While it is clear that behavior that is "lawful but awful" should be part of a criminology that deals with social harms inflicted by the powerful, this leaves corporate and white-collar crime scholarship vulnerable to criticism that it is unable to reach agreement on its empirical domain with any clarity (Friedrichs 2015). Regulatory governance scholarship, by contrast, has avoided controversy about its scope as "it is not preoccupied with what counts as 'law', but has got on with... empirically understanding that interaction... unconstrained in scope and approach by... traditional state-centered conceptions of law" (Parker 2008, p. 355). Definitional controversies, which often distract from the arguments being made, are recurrent features of criminology as a discipline. In our view, criminology is not just a substantive subject area (studying "crime" as "education" is studied within education studies), but an undertaking committed to shedding light on processes of criminalization, the role of powerful actors and victims in these processes, the gap between legal and societal definitions of "crime," and the effectiveness of criminalization in expressing normative disapproval of behavior. Definitional ambiguities act as indices of social change, reflecting processes of transition as particular harms start to be recognized, along with power imbalances that provide opportunities for (global) entrepreneurship while leaving associated social costs unaddressed (Nelken 2012). "Corporate crimes" thus reflect ongoing processes of competition between values of shareholder reward and consumption on the one hand, and consumer protection, human rights, and ecology on the other. Examples of this include the criminalization of "big tobacco" (McCann et al. 2013) and of cartels (Haines \& Beaton-Wells 2012; Parker 2012), or the development of "green criminology" to address harms to ecosystems and animals and their resulting injustices (White 2011).

\subsection{Ambiguities of application and enforcement}

The ambiguities outlined above extend into the practical sphere of enforcement, which is disproportionately directed at smaller, less professional firms (Shapiro 1984; van Erp 2011; Parker 2012), leaving large and powerful firms untouched, as they are better at "isolating themselves from the possibility the law would apply its full force to them personally" (Parker 2012, p. 16). Enforcement thus becomes a tool for the entrenchment of structural differences between privileged and less-privileged economic actors. Regulatory responses to corporate crime, with 
their reliance on measures such as collaborative governance, administrative control, self-regulation, and thirdparty auditing, have been accused of contributing to the moral ambiguity of corporate crime by tolerating or implicitly authorizing social harms (Nelken 2012). On this view, those regulatory measures can also translate into ambivalent forms of oversight, and a permissive business regulatory culture which, if not causing offending, play an important explanatory role as "contributing precedents" (Michalowski \& Kramer 2007). Many explanations of corporate and white-collar crime, which focus on systemic causes and macro-meso-micro connections, emphasize the role that ambiguities in the regulatory context play in shaping individual behavior (Nelken 2012), as in the Madoff frauds (Young 2012), the Deepwater Horizon oil spill (Bradshaw 2015), and in real estate frauds (van de Bunt \& van Wingerde 2015). These factors are also relevant in the explanation of failures of transnational regulation and governance.

Debates about criminalization highlight an additional source of the ambiguity of corporate and white-collar crime. Norwegian sociologist Vilhelm Aubert (1952) identified the "pacifying" role of criminalization as a means for symbolically solving social conflict. It remains relevant to understanding how the legal criminalization of corporate conduct serves to symbolically satisfy public demands for "justice," but in forms that are not stringently enforced, so that the economic interests of elites are not damaged. An important finding from early "criminological" regulatory scholarship was that ambiguities are not just the cause of differential criminalization practices, but also their effect; that is, they are produced in response to the interests of prevailing economic, social, and political formations (Carson 1982). "Special” regulatory frameworks, which view regulations as quasi-legal and as existing to facilitate, rather than restrain, the operation of firms, may be instituted to "exceptionalize" key industries (Carson 1982, Ch.5). Contemporary examples are provided via the use of "deferred prosecution agreements" or arbitrage in financial regulation, which, from a regulatory perspective, are evaluated on their effectiveness as governance arrangement for corporate behavior (Barkow \& Barkow 2011). Such instrumental uses of criminal law may, however, undermine rather than support the public legitimation of criminalization processes (Lacey 2004). For criminologists, they may be read as expressions of corporate exceptionalism and social injustice, and evaluated according to their normative and deterrent effects. Critical criminologists have often taken the role of accuser, asking loaded questions about why there is no moral indignation over corporate crime (Laufer 2014), why prosecutors compromise with corporations that are "too big to jail" (Garrett 2014), what can be done when wrongdoers are "too big to fail [but] too powerful to jail" (Pontell et al. 2014), "why not jail" the powerful (Steinzor 2014), and how to respond to the "theft of a nation" (Barak 2012). Empirically, this is not clear-cut; the lengthy sentences applied in dramatic American corporate fraud cases far exceed those that might occur in Europe, for example (Levi 2016), and public perceptions of the need to punish harm-causing companies seem to strengthen in times of austerity (O'Connor Shelley \& Hogan 2013).

The ideological character of this critical corporate crime scholarship contrasts with the tenor of regulatory governance scholarship, which has itself been critiqued for tending to translate political issues into instrumental problems (Mascini 2013). Similar to critiques addressed to political science (Mead 2010; Flinders 2013) and "administrative" criminology (Matthews 2017), regulatory governance risks becoming overly policy-oriented or even scholastic, rather than addressing deep structural causes. John Braithwaite, a social advocate and an outstanding academic, has argued for the combination of this commitment to social movements with a commitment to good science via research that integrates explanatory and normative theory (Braithwaite 2002, p. x). Similarly, the systematic, objective account of deterrence-based approaches to corporate crime undertaken by Simpson et al. (2014) highlights the role that evidence of this sort plays in underpinning normative theory. The marrying of these interpretative tendencies with evidence-based objectivity of this sort allows criminological scholarship to assist regulatory governance scholars in engaging in a more politicized analysis of the empirical relation between states and markets (Mascini 2013) and of the consequences of regulatory governance arrangements for both the elites and the "powerless." The difficulty of doing so perhaps accounts for the relative decline in the visibility and influence of corporate crime scholarship.

\subsection{Ambiguities of social context and reaction}

This ambiguity is not limited to formal social controls. A particular contribution of criminological scholarship has been the study of ambiguity in media representations of corporate and white-collar crime. Criminological 
scholarship has found that typical media narratives reinforce the moral ambiguity of corporate crime rather than condemn it, portraying the glamorous lifestyles of white-collar criminals (Levi 2006) rather than analyzing the underlying structural causes of corporate crimes, and framing corporate crimes as accidents rather than purposive actions (Wright et al. 1995; Machin \& Mayr 2013; Buist \& Leighton 2015). The regulatory impacts of publicity sanctions and "naming-and-shaming" processes are also undermined by the capacity of larger offenders to utilize their resources to counter negative publicity via portrayal as legitimate equal parties in pro-business national media. At the same time, smaller businesses continue to be portrayed as "rogue traders" in consumer-oriented local media (van Erp 2013), and regulators are portrayed as overzealous in general (Almond 2009). By discursively constructing corporate crimes as ambiguous, news media contribute to a societal climate in which corporate crime is accepted as a fact of life (Wright et al. 1995; Rosoff 2007; Williams 2008), while similar acts of wrongdoing by public institutions are censured much more heavily (Greer \& McLaughlin 2017). These representations influence the depth of public knowledge about elite deviance and diminish perceptions of seriousness and punitiveness. Recent research finds similar perceptions with internet news consumers (Michel et al. 2016) but also suggests that news consumers with existing (pro-capitalism) worldviews tend to reject information about crimes of the powerful (Michel 2018). Collectively, this demonstrates that the media (including social media) should be considered significant governance actors (for better or worse), but remain largely overlooked within regulatory governance studies.

The scholarship on state-corporate crime is perhaps the most prominent strand of scholarship addressing the political and power aspects of corporate crime. State-corporate crime was introduced as a sensitizing concept to better understand how illegal or socially injurious actions result from symbiotic state-corporate relations that create "a political culture and organizational frameworks that ultimately led to heinous acts that would not have occurred without that culture and those frameworks" (Michalowski \& Kramer 2007, p. 206). The study of statecorporate crime tends to focus on the social conditions of unequal power that produce crime, and politicaleconomic structures that shape the relations between states and corporations (Bernat \& Whyte 2017). This can take several forms: in "state-initiated" corporate crimes, political actors commission crimes and corporate actors operate at their direction or with their overt approval. More subtly, indirect versions of these relations arise within "state-facilitated" corporate crime. A third category is "corporate-facilitated state crime," in which corporations provide assistance in the commission of state crimes, a concept applied to understand, for example, how German corporations assisted in the Holocaust via the production of Zyklon B gas by IG Farben, and the construction of concentration camp ovens by Topf \& Sohne (van Baar \& Huisman 2012). Both the first and third of these categories are closely related to issues of state, political, military, and war crimes (so-called "gold-collar crime:" Brants 2007), and crimes of globalization, all areas of study that are relevant to regulatory governance scholars.

Perhaps most relevant to issues of regulation and governance, however, is the second category of "state-facilitated" corporate crime. This can occur when, rather than committing corporate crimes themselves, states share common goals with offending corporations, which would be hampered by aggressive regulation, and so they facilitate it via regulatory institutions that fail to restrain deviant business activities. Thus, governments provide the enabling institutional context for harmful corporate behavior in "regimes of permission" that create structures of corporate impunity (Whyte 2014). Perhaps the classic account of such a regime is provided by Carson's (1982) study of the offshore North Sea oil sector, where the shared interests of the UK government and the oil industry in extraction and revenue-raising led to weak regulatory oversight, a culture of risk-taking, and an acceptance of widespread harm as an acceptable cost of pursuing the national interest. Another example of state-facilitated corporate crime is provided by the "benign neglect" of fraud by the Federal Deposit Insurance Corporation in the American commercial banking industry, contributing to the banking crisis of 2008 (Tillman 2015) and the more general anomic regulatory culture preceding it (Young 2012). Within the extractive industry, state-corporate crime is apparent in the reliance of transnational corporations on repressive state apparatuses to impose their corporate will on local populations in the Niger Delta oilfields (Ezeonu 2015, p. 100) and the Colombian gold mining industry (Zaitch \& Gutierrez Gómez 2015). Global warming is also viewed as a matter of state-corporate crime, with climate-change denial exposed as a concerted action of multinational corporate and state actors to collectively block efforts to mitigate greenhouse gas emissions and exclude the issue of climate change from the political arena. Rather than simply co-creating a permissive environment, corporate interests have directly 
influenced political decisionmaking, creating regulatory regimes that suppress progressive change (Kramer \& Michalowski 2012).

The interactionist framing of state-corporate crime scholarship provides a direct parallel to the institutional structures found within governance studies. Twenty-first century processes of globalization and digitalization have created "counter-hegemonic transnational networks" (Ward \& Green 2016, p. 229) through which victims of state crime can secure justice; transnational legal pluralism has thus created more diverse opportunities for "criminalization," broadly understood, than traditional concepts of state and state-corporate crime acknowledged (Ward \& Green 2016). However, the market-government-civil society "governance triangle" that underpins regulatory scholarship is cast in a more problematic light if we focus on the nature of the political power that corporations wield in the era of globalization (Barkan 2013; Wilks 2013). Thus, governance scholars have been called upon to pay "much more attention to the political strategic environment that informs diverse regulatory goals" (Coen \& Pegram 2015, p. 418). The dichotomy between the economic and political sphere is more complex than corporate crime scholarship has often portrayed it as being, but is also more problematic than regulation and governance scholarship has tended to view it; thus, state-corporate crime scholarship offers important insights for the development of both fields.

\section{The relationship between public and private}

The sharpest contrast between white-collar crime and regulatory governance is that around the space and attention given to issues of non-state governance. Corporate criminology has tended to focus on the formal exercise of state power, whereas regulation and governance is a field where traditional (state) criminalization is relatively rare, as a component of decentered, compliance-seeking systems. Most examples of "governance" approaches explicitly involve finding alternatives to state-led intervention. This divide has hardened since Sutherland (1949) defined white-collar crime as encompassing issues of civil liability and non-criminal harms, and since Ayres and Braithwaite (1992) conceptualized regulation as involving the state, business, and civil society. In fact, a defining feature of the emergent research of the 1990s and 2000s at the intersection of corporate criminology and regulatory governance was that it addressed the interaction between deterrence and compliance, and the ways in which state sanctions and social pressures reinforced each other's effectiveness (Gunningham et al. 1999, 2004, 2005; Lacey 2004; Thornton et al. 2005, 2009; Kagan et al. 2011). Many contemporary corporate criminologists have thus been prompted to interrogate the complexity and changing nature of this public/private frontier (e.g. McGrath 2015; Shi \& van Rooij 2016; Parker et al. 2017; King \& Lord 2018).

Private or "informal" disciplinary mechanisms, which are often premised on ideas of corporate citizenship, can thus be seen as a supplement to state-led efforts at corporate control rather than as a direct alternative, although not an unproblematic one from a criminological point of view, not least that their legitimacy and effectiveness are empirically and conceptually questionable (Gibbs 2012; Rorie 2015; King \& Lord 2018). Despite this, critical criminological scholarship seems wedded to "big government" without recognizing the fundamental transformation of the regulatory capitalist state and the explosion of hybrid forms of governance that has occurred in recent years (Levi-Faur 2012). Critical corporate criminologists perceive private audits, self-regulation, publicprivate collaboration, and corporate governance to function primarily as reputational window-dressing, offering a purely cosmetic form of compliance ("Potemkin villages:" Gray 2006) that still allows for the exploitation of legal loopholes (Nelken 2012), and as an expression of the ambiguities and privileges surrounding the crimes of the powerful. At the same time, however, critical scholars also critique the relative weakness and limited reach of state-based regulation in responding to globalized harms and transnational corporate actors (Barkan 2013; Friedrichs \& Rothe 2014).

This critical view of regulatory governance narrows our understanding by equating the regulatory state with neoliberal deregulation (Levi-Faur 2013). It arguably undervalues the importance of augmenting or aligning the formal criminal law with more bottom-up community, digital, and market-based forms of social control (Lacey 2004; Ward \& Green 2016). There are non-criminal systems of administrative sanctioning that increasingly possess greater power, capacity, and deterrent impact than prosecutorial agencies, and fields of "beyond-the-state" regulation that exert just as, if not more, effective control than state-led alternatives (Haines 1999; Grabosky 2013; Parker et al. 2017). As such, the criminological study of "criminalization" should look beyond traditional 
state prosecution and take into account the full diversity of state, community, and market actors, and modalities, involved in the "regulatory space" of criminalization (Lacey 2004; Rorie 2015). It should also pay more attention to the punitive capacity of a fuller range of private and informal "sanctions," including professional bans, media "naming and shaming" campaigns (van Erp 2011), social media accountability (Grabosky 2013), and systems of civil penalties, that contribute to the practice of corporate social control (Black 2002). The growing recognition of private security (closed-circuit TV, private policing) and administrative sanctioning (such as anti-social behavior orders in the UK) within mainstream criminology, along with the increasing use made of corporate policing to enable secrecy and control, and to limit reputational damage (Meerts 2014; van Erp 2017), suggests that there is a pressing need for corporate criminology scholarship to expand its focus to account for these variations (Bures \& Carrapico 2017).

On the other hand, regulatory governance scholars sometimes appear to paint too rosy a picture of publicprivate collaborative governance, private regulation, and the power of market sanctions (Coen \& Pegram 2015). The capacity of private actors and public-private governance networks to process information, avoid "groupthink," and support accountability, have been found to be limited by empirical studies across a variety of sectors, from banking (Ford 2010), to deepwater drilling (Mills \& Koliba 2015), to cybersecurity (van Erp 2017). Common flaws found in such settings include a tendency for self-reinforcing "confirmation biases" to emerge in the decisionmaking of regulatory actors who closely share both operational assumptions and industry cultures (Ford 2010, p. 485; Mills \& Koliba 2015, p. 86). Case studies have also identified the ways in which corporate control limits the application of core constitutional principles such as transparency, privacy, and due process (Benish \& Levi-Faur 2012). Examples include the curtailment of media reporting on corporate environmental crimes, such as British Petroleum banning journalists from the site of the Macondo Oil Spill (Bradshaw 2015), or aggressive litigation by Trafigura against attempts by The Guardian and the $\mathrm{BBC}$ to report on the Probo Koala toxic waste dump in Côte d'Ivoire (van Wingerde 2015). The regulatory state itself has been implicated in the process of managing and insulating against the consequences of institutional corruption scandals, particularly those that occur within public institutions (Greer \& McLaughlin 2017) or illegal transnational trade of environmental commodities (Bisschop 2012). But a body of corporate crime scholarship built predominantly on case studies has only a limited capacity to support wide-ranging theorization and generalization (Shover \& Hochstetler 2006; Rorie et al. 2018), meaning that the integration of these findings into regulatory governance scholarship has been limited.

\section{Conclusion: Toward an integrated research agenda?}

The impetus behind this paper arose from our mutual puzzlement over the disciplinary divide that has grown between regulation and governance research and corporate criminology in recent years. By exploring the differences in approach between these two disciplinary areas, and of potential avenues of fertilization between them, we have established that the dominant voice of "corporate criminology," at least as perceived within the regulation and governance field, is one that has failed to offer much in the way of innovation, methodological scope, and impact upon broader debate, apart from an oppositional form of contrast. But our investigation has demonstrated that, contrary to this perception, which is perhaps widespread within regulation and governance spheres, corporate criminology (broadly understood) does have much of value to offer. Adopting an empirically informed, integrated criminological lens can inform inquiries into the role of agency, individual motivations, and organizational culture in shaping offending and noncompliance, broadening the scope from the institutionalist and economic rationalities predominant in regulatory governance scholarship. More critical forms of corporate criminology (and particularly, scholarship on state-corporate crime) do problematize issues of structural power and ambiguity in very valuable ways, offering a politicized perspective on state-corporate relations in terms of power imbalances and perhaps answering calls for more public rather than policy-oriented scholarship. And both interpretive and empirical forms of corporate criminology highlight the limitations of private governance and self-regulation, and thus assist regulatory governance scholarship in developing a more realistic account of the governance capacity of private actors. These potential contributions do not undermine the value of regulatory governance scholarship, but underline the value of looking at the same issue in more than one way. 
We have also noted that critical corporate criminology scholarship has often remained relatively unresponsive to some of the key concerns of mainstream criminology (such as desistance, restorative justice, and situational prevention) and regulation and governance studies (such as private and administrative sanctioning, publicity, and social accountability). As we have argued, a narrow focus on punitive state intervention creates a risk that corporate criminology offers only an incomplete understanding of the current practice of governing corporate crimes, in which prevention, self-regulation, and social control may be more important than criminal justice. At the same time, questions over the role that prosecution plays in shaping corporate behavior remain unanswered, and debate over whether the regulatory pyramid functions and whether (and how) the "benign big gun" of criminal sanctioning really works is as alive as when Responsive Regulation was written in 1992. The formations of private governance that are so central to regulatory studies give rise, when applied via mechanisms such as private security and corporate public relations, to vital questions about transparency, public accountability, and democratic oversight of corporate activity, all of which impact on public support for regulation (Benish \& Levi-Faur 2012). On each of these fronts, corporate criminology has an opportunity to make a major contribution to our understanding of the dynamics of regulation and control, but has arguably not been engaged with in such a way as to fulfill these needs in practice.

At the same time, assessments of the effectiveness and socio-political implications of non-criminal regulatory arrangements could benefit greatly from a more sustained engagement with longstanding criminological concepts such as deterrence, punitiveness, and culture. For example, in what ways are administrative sanctions punitive, and do they deter in the same way as criminal sanctions? How are regulatory inspections and certification audits experienced as different, and does the "threat" of withdrawal of a private certificate actually shape behavior in a deterrent way? How and why do regulatory systems and compliant behaviors break down, and what influence do cultural formations (internal and external to the corporation) have on these processes? Important research questions also arise at the intersection of criminal justice and governance, in particular over the indirect and extended governance impacts of criminal prosecution. The globalization of corporate activity means that corporations are exposed to a shifting and diverse range of regimes of control, many of which involve the threat of prosecution. An increased emphasis on criminalization within one regime, for example, the United States' Racketeer Influenced and Corrupt Organizations (RICO) Act, or the Organisation for Economic Co-operation and Development's (OECD's) 1997 Convention on Combatting Bribery of Foreign Public Officials, may have effects on governance in others, leading to regulatory disruptions and the imposition of radically different norms. It was the threat of prosecution of Swiss banks under the RICO Act that led Switzerland to introduce tax secrecy regulations and abandon a longstanding division between private finance and public law (Emmenegger 2015). Similarly, the OECD Convention led many national jurisdictions around the world to reform their rules on corporate criminal liability, resulting in an expansion of the idea of "corporate homicide" into previously resistant regimes (Almond 2013). Criminalization is a tool for corporate control, but it is also capable of radically rearranging existing governance arrangements, and of more strongly condemning rule transgressions, in moral terms, than administrative or civil regulation. These tendencies need to be better understood, and accounted for, along with the political contexts within which regulation develops.

Our core ambition in this paper has been to demonstrate the opportunities that would arise from a convergence of attention and understanding between the fields of corporate criminology and regulation and governance research, rather than to advance one at the expense of the other. It is important to be realistic about the limits of our understanding, and to recognize that the disciplinary traditions within which we position ourselves carry significant implications in terms of the focus of our attention, and our grasp of what is possible and desirable. Regulation and governance scholars are thus presented with an opportunity to broaden the focus of their attention, and to question core assumptions about the organizational nature of action, the apolitical nature of regulatory arrangements, and the functionality of governance-based arrangements. The existing corporate crime scholarship offers a number of ways in which these assumptions can be challenged. It also highlights the potential for regulation and governance research to influence a broader field of inquiry by demonstrating the variability, significance, and complexity of the realities of the regulatory domain, and the ways in which governance-based solutions can resolve some of the entrenched difficulties of corporate crime control. This is a process of opening conversations and prompting interactions between scholars working in parallel, and who currently only "touch from a distance;" it is hoped that this review can provide a starting point for this process. 


\section{Acknowledgments}

This paper has benefited from the input of participants at the European Working Group on Organisational Crime (EUROC) Research Symposium, at Utrecht University on 31 August 2017, and in the EUROC stream at the European Society of Criminology conference, at Cardiff University on 15 September 2017. In particular, the authors are grateful for the comments and input of Fiona Haines, Wim Huisman, Mike Levi, and Colin Scott.

\section{References}

Almond GA (1988) Separate Tables: Schools and Sects in Political Science. PS: Political Science and Politics 21, 828-842.

Almond P (2009) The Dangers of Hanging Baskets: "Regulatory Myths" and Media Representations of Health and Safety Regulation. Journal of Law and Society 36, 352-375.

Almond P (2013) Corporate Manslaughter and Regulatory Reform. Palgrave Macmillan, Basingstoke.

Almond P, Gray GC (2017) Frontline Safety: Understanding the Workplace as a Site of Regulatory Engagement. Law \& Policy $39,5-26$.

Aubert V (1952) White-collar Crime and Social Structure. American Journal of Sociology 58, 263-271.

Ayres I, Braithwaite J (1992) Responsive Regulation: Transcending the Deregulation Debate. OUP, Oxford.

Baldwin R (1995) Rules and Government. Clarendon Press, Oxford.

Baldwin R, Scott C, Hood C (1998) A Reader on Regulation. OUP, Oxford.

Barak G (2012) Theft of a Nation: Wall Street Looting and Federal Regulatory Colluding. Rowman \& Littlefield, New York.

Barak G (2015) The Routledge International Handbook of the Crimes of the Powerful. Routledge, London.

Barkan J (2013) Corporate Sovereignty: Law and Government under Capitalism. University of Minnesota Press, Minneapolis.

Barkow AS, Barkow RE (e) (2011) Prosecutors in the Boardroom: Using Criminal Law to Regulate Corporate Conduct. New York University Press, New York.

Benish A, Levi-Faur D (2012) New Forms of Administrative Law in the Age of Third Party Government. Public Administration $90,886-900$.

Benson ML, van Slyke SR, Cullen FT (2016) Core Themes in the Study of White-collar Crime. In: van Slyke SR, Benson ML, Cullen FT (eds) The Oxford Handbook of White-collar Crime, pp. 1-24. OUP, Oxford.

Bernat I, Whyte D (2017) State-corporate Crime and the Process of Capital Accumulation: Mapping a Global Regime of Permission from Galicia to Morecambe Bay. Critical Criminology 25, 71-86.

Bichler G, Schoepfer A, Bush S (2015) White Collars and Black Ties: Interlocking Social Circles of Elite Corporate Offenders. Journal of Contemporary Criminal Justice 31, 279-296.

Bisschop L (2012) Out of the Woods: The Illegal Trade in Tropical Timber and a European Trade Hub. Global Crime 13, 191-212.

Black J (2002) Critical Reflections on Regulation. Australian Journal of Legal Philosophy 27, 1-36.

Black J (2008) Constructing and Contesting Legitimacy and Accountability in Polycentric Regulatory Regimes. Regulation \& Governance 2, 137-164.

Bonger WA (1916) Criminality and Economic Conditions. Little, Brown \& Co., Boston.

Bradshaw EA (2015) “Obviously, We're All Oil Industry”: The Criminogenic Structure of the Offshore Oil Industry. Theoretical Criminology 19, 376-395.

Braithwaite J (1984) Corporate Crime in the Pharmaceutical Industry. Routledge \& Kegan Paul, London.

Braithwaite J (2000) The New Regulatory State and the Transformation of Criminology. British Journal of Criminology 40, $222-238$.

Braithwaite J (2002) Restorative Justice \& Responsive Regulation. OUP, Oxford.

Braithwaite J, Coglianese C, Levi-Faur D (2007) Can Regulation and Governance Make a Difference? Regulation \& Governance $1,1-7$.

Braithwaite J, Drahos P (2000) Global Business Regulation. CUP, Cambridge, UK.

Braithwaite J, Makkai T (1991) Testing an Expected Utility Model of Corporate Deterrence. Law and Society Review 25, 7-40.

Brants C (2007) Gold-collar Crime: The Peculiar Complexities and Ambiguities of War Crimes, Crimes Against Humanity, and Genocide. In: Pontell NH, Geis GL (eds) International Handbook of White-collar and Corporate Crime, pp. 309-326. Springer, New York.

Breyer S (1982) Regulation and its Reform. Harvard University Press, Cambridge, MA.

Buist CL, Leighton P (2015) Corporate Criminals Constructing White-collar Crime: Or Why There is no Corporate Crime on the USA Network's White Collar Series. In: Barak G (ed) The Routledge International Handbook of the Crimes of the Powerful, pp. 73-85. Routledge, London.

Burawoy M (2005) For Public Sociology. American Sociological Review 70, 4-28.

Bures O, Carrapico H (2017) Private Security Beyond Private Military and Security Companies: Exploring Diversity within Private-Public Collaborations and its Consequences for Security Governance. Crime, Law \& Social Change 67, $229-243$.

Calavita K, Pontell HN (1990) "Heads I Win, Tails You Lose": Deregulation, Crime, and Crisis in the Savings and Loan Industry. Crime \& Delinquency 36, 309-341.

Carson WG (1982) The Other Price of Britain's Oil: Safety and Control in the North Sea. Martin Robertson, Oxford.

Casey DK, Lawless JS (2011) The Parable of the Poisoned Pork: Network Governance and the 2008 Irish Pork Dioxin Contamination. Regulation \& Governance 5, 333-349. 
Cashore B, Auld G, Renckens S (2011) The Impact of Private, Industry and Transnational Civil Society Regulation and their Interaction with Official Regulation. In: Parker C, Nielsen VL (eds) Explaining Compliance: Business Responses to Regulation, pp. 343-376. Edward Elgar, Cheltenham.

Clinard M, Yeager P (1980) Corporate Crime. Free Press, New York.

Cloward RA, Ohlin LE (1962) Delinquency and Opportunity: A Theory of Delinquent Gangs. Free Press, Glencoe, IL.

Coen D, Pegram T (2015) Wanted: A Third Generation of Global Governance Research. Governance 28, 417-420.

Croall H (2015) White-collar Crime in Europe: Afterword. In: van Erp J, Huisman W, Vande Walle G (eds) The Routledge Handbook of White-collar and Corporate Crime in Europe, pp. 533-547. Routledge, London.

Edelman LB, Uggen C, Erlanger HS (1999) The Endogeneity of Legal Regulation: Grievance Procedures as Rational Myth. American Journal of Sociology 105, 406-454.

Emmenegger P (2015) The Long Arm of Justice: US Structural Power and International Banking. Business and Politics 17, 473-493.

Etienne J (2015) Different Ways of Blowing the Whistle: Explaining Variations in Decentralized Enforcement in the UK and France. Regulation \& Governance 9, 309-324.

Ezeonu I (2015) Capital and Catharsis in the Nigerian Petroleum Extraction Industry: Lessons on the Crimes of Globalization. In: Barak G (ed) The Routledge International Handbook of the Crimes of the Powerful, pp. 89-104. Routledge, London.

Fligstein N, Roehrkasse AF (2016) The Causes of Fraud in the Financial Crisis of 2007 to 2009: Evidence from the Mortgagebacked Securities Industry. American Sociological Review 81, 617-643.

Flinders M (2013) The Tyranny of Relevance and the Art of Translation. Political Studies Review 11, $149-167$.

Ford C (2010) New Governance in the Teeth of Human Frailty: Lessons from Financial Regulation. Wisconsin Law Review 2010, 57, 441-487.

Ford C (2013) Prospects for Scalability: Relationships and Uncertainty in Responsive Regulation. Regulation \& Governance 7 , $14-29$.

Fransen L, Conzelmann T (2015) Fragmented or Cohesive Transnational Private Regulation of Sustainability Standards? A Comparative Study. Regulation \& Governance 9, 259-275.

Friedrichs DO (2015) White-collar Crime in Europe: American Reflections. In: van Erp J, Huisman W, Vande Walle G (eds) The Routledge Handbook of White-collar and Corporate Crime in Europe, pp. 548-560. Routledge, London.

Friedrichs DO, Rothe DL (2014) State-Corporate Crime and Major Financial Institutions: Interrogating an Absence. State Crime Journal 3, 146-162.

Garland D (1997) Governmentality and the Problem of Crime: Foucault, Criminology, Sociology. Theoretical Criminology 1, 173-214.

Garrett BL (2014) Too Big to Jail: How Prosecutors Compromise with Corporations. Harvard University Press, Cambridge, MA.

Geis G (2016) The Roots and Variant Definitions of the Concept of "White-collar Crime". In: van Slyke SR, Benson ML, Cullen FT (eds) The Oxford Handbook of White-collar Crime, pp. 25-38. OUP, Oxford.

Gibbs C (2012) Corporate Citizenship and Corporate Environmental Performance. Crime, Law and Social Change 57, 345-372.

Grabosky P (2013) Beyond Responsive Regulation: The Expanding Role of Non-state Actors in the Regulatory Process. Regulation \& Governance 7, 114-123.

Grabosky P, Braithwaite J (1986) Of Manners Gentle: Enforcement Strategies of Australian Business Regulatory Agencies. OUP, Oxford.

Gray GC (2006) The Regulation of Corporate Violations: Punishment, Compliance, and the Blurring of Responsibility. British Journal of Criminology 46, 875-892.

Gray GC, Silbey SS (2014) Governing Inside the Organization: Interpreting Regulation and Compliance. American Journal of Sociology 120, 96-145.

Greer C, McLaughlin E (2017) Theorizing Institutional Scandal and the Regulatory State. Theoretical Criminology 21, 112-132.

Gunningham N, Kagan RA, Thornton D (2004) Social License and Environmental Protection: Why Businesses Go Beyond Compliance. Law \& Social Inquiry 29, 307-341.

Gunningham N, Phillipson M, Grabosky P (1999) Harnessing Third Parties as Surrogate Regulators: Achieving Environmental Outcomes by Alternative Means. Business Strategy and the Environment 8, 211-224.

Gunningham NA, Thornton D, Kagan RA (2005) Motivating Management: Corporate Compliance in Environmental Protection. Law \& Policy 27, 289-316.

Haines F (1997) Corporate Regulation: Beyond 'Punish or Persuade. OUP, Oxford.

Haines F (1999) Innocent Deaths and Regulatory Failure: A Case Study of Change in the Absence of Punishment. International Journal of the Sociology of Law 27, 23-50.

Haines F (2011a) Addressing the Risk, Reading the Landscape: The Role of Agency in Regulation. Regulation \& Governance 5, $118-144$

Haines F (2011b) The Paradox of Regulation: What Regulation Can Achieve and What it Cannot. Edward Elgar, Cheltenham, UK.

Haines F (2014) Corporate Fraud as Misplaced Confidence? Exploring Ambiguity in the Accuracy of Accounts and the Materiality of Money. Theoretical Criminology 18, 20-37.

Haines F, Beaton-Wells C (2012) Ambiguities in Criminalizing Cartels: A Political Economy. British Journal of Criminology 52, 953-973.

Haines F, Hall A (2004) The Law and Order Debate in Occupational Health and Safety. Journal of Occupational Health and Safety: Australia and New Zealand 20, 263-273. 
Hawkins K (1983) Bargain and Bluff: Compliance Strategy and Deterrence in the Enforcement of Regulation. Law \& Policy 5, 35-73.

Hawkins K (1990) Compliance Strategy, Prosecution Policy, and Aunt Sally: A Comment on Pearce and Tombs. British Journal of Criminology 30, 444-466.

Hebberecht P (2015) Willem Bonger: The Unrecognized European Pioneer of the Study of White-collar Crime. In: van Erp J, Huisman W, Vande Walle G (eds) The Routledge Handbook of White-collar and Corporate Crime in Europe, pp. 125-132. Routledge, London.

Hirschi T (1969) Causes of Delinquency. University of California Press, Berkeley, CA.

Hutter B, Lloyd-Bostock S (2017) Regulatory Crisis: Negotiating the Consequences of Risk, Disasters and Crises. Cambridge University Press, Cambridge.

Jackson J, Bradford B, Hough M, Myhill A, Quinton P, Tyler TR (2012) Why Do People Comply with the Law? Legitimacy and the Influence of Legal Institutions. British Journal of Criminology 52, 1051-1071.

Kagan RA, Gunningham N, Thornton D (2011) Fear, Duty, and Regulatory Compliance: Lessons from Three Research Projects. In: Parker C, Nielsen VL (eds) Explaining Compliance: Business Responses to Regulation, pp. 37-58. Edward Elgar, Cheltenham, UK.

Kagan RA, Scholz JT (1984) The "Criminology" of the Corporation and Regulatory Enforcement Strategies. In: Hawkins K, Thomas JM (eds) Enforcing Regulation, pp. 67-95. Kluwer-Nijhoff, Boston.

King C, Lord N (2018) Negotiated Justice and Corporate Crime: The Legitimacy of Civil Recovery Orders and Deferred Prosecution Agreements. Palgrave MacMillan, Basingstoke.

Klinkhammer J (2015) Varieties of Corruption in the Shadow of Siemens: A Modus Operandi Study of Corporate Crime on the Supply Side of Corrupt Transactions. In: van Erp J, Huisman W, Vande Walle G (eds) The Routledge Handbook of White-collar and Corporate Crime in Europe, pp. 318-336. Routledge, London.

Koop C, Lodge M (2017) What is Regulation? An Interdisciplinary Concept Analysis. Regulation \& Governance 11, 95-108.

Kramer RC, Michalowski RJ (2012) Is Global Warming a State-Corporate Crime? In: White R (ed) Climate Change from a Criminological Perspective, pp. 71-88. Springer, New York.

Lacey N (2004) Criminalization as Regulation: The Role of Criminal Law. In: Parker C, Scott C, Lacey N, Braithwaite J (eds) Regulating Law, pp. 144-167. OUP, Oxford.

Laufer WS (2014) Where is the Moral Indignation over Corporate Crime? In: Brodowski D, Espinoza de los Monteros de la Parra M, Tiedemann K, Vogel J (eds) Regulating Corporate Criminal Liability, pp. 19-31. Springer, New York.

Levi M (2006) The Media Construction of Financial White-collar Crimes. British Journal of Criminology 46, $1037-1057$.

Levi M (2016) Sentencing Respectable Offenders. In: van Slyke SR, Benson ML, Cullen FT (eds) The Oxford Handbook of White-collar Crime, pp. 582-602. OUP, Oxford.

Levi-Faur D (2011) Handbook on the Politics of Regulation. Edward Elgar, Cheltenham, UK.

Levi-Faur D (2012) From "Big Government" to "Big Governance"? In: Levi-Faur D (ed) The Oxford Handbook of Governance, pp. 3-18. OUP, Oxford.

Levi-Faur D (2013) The Odyssey of the Regulatory State: From a "Thin” Monomorphic Concept to a "Thick" and Polymorphic Concept. Law \& Policy 35, 29-50.

Lodge M (ed) (2016) Regulation Scholarship in Crisis? CARR Discussion Paper No. 84, pp. 1-7.

Machin D, Mayr A (2013) Corporate Crime and the Discursive Deletion of Responsibility: A Case Study of the Paddington Rail Crash. Crime, Media, Culture: An International Journal 9, 63-82.

Makkai T, Braithwaite J (1991) Criminological Theories and Regulatory Compliance. Criminology 29, 191-220.

Mascini P (2013) Why was the Enforcement Pyramid so Influential? And What Price was Paid? Regulation \& Governance 7 , $48-60$.

Matza D (1964) Delinquency and Drift. Wiley, New York, NY.

Matthews R (2017) False Starts, Wrong Turns and Dead Ends: Reflections on Recent Developments in Criminology. Critical Criminology 25, 577-591.

McCann M, Haltom W, Fisher S (2013) Criminalizing Big Tobacco: Legal Mobilization and the Politics of Responsibility for Health Risks in the United States. Law \& Social Inquiry 38, 288-321.

McGrath J (2015) Corporate and White-collar Crime in Ireland: A New Architecture of Regulatory Enforcement. Manchester University Press, Manchester.

Mead LM (2010) Scholasticism in Political Science. Perspectives on Politics 8, 453-464.

Meerts C (2014) Corporate Security: Governing through Private and Public Law. In: Walby K, Lippert R (eds) Corporate Security in the 21st Century: Theory and Practice in International Perspective, pp. 97-115. Palgrave MacMillan, Basingstoke.

Merton RK (1957) Social Theory and Social Structure. Free Press, Glencoe, IL.

Michalowski RJ, Kramer RC (2007) State-Corporate Crime and Criminological Inquiry. In: Pontell HN, Geis GL (eds) International Handbook of White-collar and Corporate Crime, pp. 200-219. Springer, New York.

Michel C (2018) Cognitive Dissonance Resolution Strategies After Exposure to Corporate Violence Scenarios. Critical Criminology 26, 1-28.

Michel C, Heide KM, Cochran JK (2016) The Consequences of Knowledge about Elite Deviance. American Journal of Criminal Justice 41, 359-382.

Mills RW, Koliba CJ (2015) The Challenge of Accountability in Complex Regulatory Networks: The Case of the Deepwater Horizon Oil Spill. Regulation \& Governance 9, 77-91.

Nelken D (2012) White-collar and Corporate Crime. In: Maguire M, Morgan R, Reiner R (eds) The Oxford Handbook of Criminology, 5th edn, pp. 623-659. OUP, Oxford.

Nielsen VL, Parker C (2012) Mixed Motives: Economic, Social, and Normative Motivations in Business Compliance. Law \& Policy 34, 428-462. 
O'Connor Shelley T, Hogan MJ (2013) Assessing the Impact of Economic Insecurity on Willingness to Impose Punishment for Pollution. In: South N, Brisman A (eds) Routledge International Handbook of Green Criminology, pp. $282-299$. Routledge, London.

Overdevest C, Zeitlin J (2014) Assembling an Experimentalist Regime: Transnational Governance Interactions in the Forest Sector. Regulation \& Governance 8, 22-48.

Parker C (2008) The Pluralization of Regulation. Theoretical Inquiries in Law 9, 349-369.

Parker C (2012) Economic Rationalities of Governance and Ambiguity in the Criminalization of Cartels. British Journal of Criminology 52, 974-996.

Parker C, Carey R, De Costa J, Scrinis G (2017) Can the Hidden Hand of the Market be an Effective and Legitimate Regulator? The Case of Animal Welfare under a Labeling for Consumer Choice Policy Approach. Regulation \& Governance 11, 368-387.

Parker C, Nielsen VL (2011) Introduction. In: Parker C, Nielsen VL (eds) Explaining Compliance: Business Responses to Regulation, pp. 1-36. Edward Elgar, Cheltenham, UK.

Passas N (1990) Anomie and Corporate Deviance. Contemporary Crises 14, 157-178.

Paternoster R, Simpson S (1993) A Rational Choice Theory of Corporate Crime. In: Clarke RV, Felson M (eds) Routine Activity and Rational Choice, Advances in Criminological Theory, vol. 5, pp. 37-56. Transaction Press, New Brunswick.

Pautz M, Rinfret S, Rorie M (2017) Understanding the Regulatory Thicket: Interactions among State Environmental Regulators and Regulatees. International Journal of Public Administration 40, 101-114.

Pearce F (1976) Crimes of the Powerful: Marxism, Crime and Deviance. Pluto Press, London.

Pearce F, Tombs S (1990) Ideology, Hegemony and Empiricism: Compliance Theories of Regulation. British Journal of Criminology 30, 423-443.

Picciotto S (2017) Regulation: Managing the Antinomies of Economic Vice and Virtue. Social \& Legal Studies 26, 676-699.

Piquero NL, Moffitt TE (2014) Can Childhood Factors Predict Workplace Deviance? Justice Quarterly 31, 664-692.

Pontell HN (2016) Theoretical, Empirical, and Policy Implications of Alternative Definitions of "White-collar Crime": "Trivializing the Lunatic Crime Rate". In: van Slyke SR, Benson ML, Cullen FT (eds) The Oxford Handbook of White-collar Crime, pp. 39-58. OUP, Oxford.

Pontell HN, Black WK, Geis G (2014) Too Big to Fail, too Powerful to Jail? On the Absence of Criminal Prosecutions after the 2008 Financial Meltdown. Crime, Law and Social Change 61, 1-13.

Punch M (2000) Suite Violence: Why Managers Murder and Corporations Kill. Crime, Law and Social Change 33, $243-280$.

Ramirez MK (2016) Oversight and Rule Making as Political Conflict. In: van Slyke SR, Benson ML, Cullen FT (eds) The Oxford Handbook of White-Collar crime, pp. 479-502. OUP, Oxford.

Reed GE, Yeager PC (1996) Organizational Offending and Neoclassical Criminology: Challenging the Reach of a General Theory of Crime. Criminology 34, 357-382.

Rorie M (2015) An Integrated Theory of Corporate Environmental Compliance and Overcompliance. Crime, Law and Social Change 64, 65-101.

Rorie M, Alper M, Schell-Busey N, Simpson SS (2018) Using Meta-analysis under Conditions of Definitional Ambiguity: The Case of Corporate Crime. Criminal Justice Studies 31, 1-24.

Rorie M, Rinfret S, Pautz M (2015) The Thin Green Line: Examining Environmental Regulation and Environmental Offending from Multiple Perspectives. International Journal of Law, Crime and Justice 43, 586-608.

Rosoff SM (2007) The Role of the Mass Media in the Enron Fraud: Cause or Cure? In: Pontell HN, Geis GL (eds) International Handbook of White-Collar and Corporate Crime, pp. 513-522. Springer, New York.

Schoepfer A, Piquero NL, Langton L (2014) Low Self-control Versus the Desire-for-Control: An Empirical Test of Whitecollar Crime and Conventional Crime. Deviant Behavior 35, 197-214.

Selznick P (1985) Focusing Organisational Research on Regulation. In: Noll RG (ed) Regulatory Policy and the Social Sciences, pp. 363-367. University of California Press, Berkeley.

Shapiro S (1984) Wayward Capitalists: Targets of the Securities and Exchange Commission. Yale University Press, New Haven, CT.

Shi Y, van Rooij B (2016) Prosecutorial Regulation in the Global South: Environmental Civil Litigation by Prosecutors in China Compared to Brazil. Regulation \& Governance 10, 44-57.

Shover N, Cullen FT (2008) Studying and Teaching White-collar Crime: Populist and Patrician Perspectives. Journal of Criminal Justice Education 19, 155-174.

Shover N, Hochstetler A (2006) Choosing White Collar Crime. CUP, Cambridge, UK.

Silbey SS (2011) The Sociological Citizen: Pragmatic and Relational Regulation in Law and Organizations. Regulation \& Governance $5,1-13$.

Simpson SS, Rorie M, Alper ME, Schell-Busey N, Laufer W, Smith NC (2014) Corporate Crime Deterrence: A Systematic Review. Campbell Systematic Reviews 10(4). https://doi.org/10.4073/csr2014.4.

Simpson SS, Paternoster R, Piquero NL (1998) Exploring the Micro-Macro Link in Corporate Crime Research. In Bamberger PA, Sonnenstuhl WL (eds) Research in the Sociology of Organizations: Deviance in and of organizations 15, pp. 35-76. Stamford, CT: JAI Press.

Simpson SS, Piquero NL (2002) Low Self-control, Organizational Theory, and Corporate Crime. Law and Society Review 36, 509-548.

Simpson SS, Rorie M (2011) Motivating Compliance: Economic and Material Motives for Compliance. In: Parker C, Nielsen VL (eds) Explaining Compliance: Business Responses to Regulation, pp. 59-77. Edward Elgar, Cheltenham, UK.

Stadler WA, Benson ML (2012) Revisiting the Guilty Mind: The Neutralization of White-collar Crime. Criminal Justice Review 37, 494-511. 
Steffensmeier DJ, Schwartz J, Roche M (2013) Gender and Twenty-first Century Corporate Crime: Female Involvement and the Gender Gap in the Enron-era of Corporate Frauds. American Sociological Review 78, 448-476.

Steinzor R (2014) Why Not Jail? Industrial Catastrophes, Corporate Malfeasance, and Government Inaction. CUP, Cambridge, UK.

Sutherland EH (1949) White-Collar Crime. Dryden Press, New York.

Sutherland EH, Cressey DR (1960) Principles of Criminology, 6th edn. Rowman \& Littlefield, New York.

Tappan P (1947) Who is the Criminal? American Sociological Review 12, 96-102.

Thornton D, Gunningham NA, Kagan RA (2005) General Deterrence and Corporate Environmental Behavior. Law \& Policy 27, 262-288.

Thornton D, Kagan RA, Gunningham N (2009) When Social Norms and Pressures Are Not Enough: Environmental Performance in the Trucking Industry. Law \& Society Review 43, 405-436.

Tillman R (2015) Bad Banks: Recurrent Criminogenic Conditions in the US Commercial Banking Industry. In: Barak G (ed) The Routledge International Handbook of the Crimes of the Powerful, pp. 265-277. Routledge, London.

Tombs S (2015) Crisis, What Crisis? Regulation and the Academic Orthodoxy. The Howard Journal of Crime and Justice 54, $57-72$.

Tombs S, Whyte D (2007) Safety Crimes. Willan Publishing, Devon, UK.

Tombs S, Whyte D (2015) The Corporate Criminal: Why Corporations Must Be Abolished. Routledge, London.

Tyler TR (2011) The Psychology of Self-regulation: Normative Motivations for Compliance. In: Parker C, Nielsen VL (eds) Explaining Compliance: Business Responses to Regulation, pp. 78-99. Edward Elgar, Cheltenham, UK.

van Baar A, Huisman W (2012) The Oven Builders of the Holocaust: A Case Study of Corporate Complicity in International Crimes. British Journal of Criminology 52(6), 1033-1050.

van de Bunt HG, van Wingerde CG (2015) 'We are All Going to be Rich': A Case Study of the Dutch Real Estate Fraud. In: van Erp J, Huisman W, Vande Walle G (eds) The Routledge Handbook of White-Collar and Corporate Crime in Europe, pp. 304-317. Abingdon, Routledge.

van Erp J (2011) Naming Without Shaming: The Publication of Sanctions in the Dutch Financial Market. Regulation \& Governance 5(3), 287-308.

van Erp J (2013) Messy Business: Media Representations of Administrative Sanctions for Corporate Offenders. Law \& Policy $35(1), 109-139$.

van Erp J (2017) New Governance of Corporate Cybersecurity: A Case Study of the Petrochemical Industry in the Port of Rotterdam. Crime, Law and Social Change 68(1), 75-93.

van Erp J, Huisman W (2017) White Collar Crime. In: Brisman A, Carrabine E, South N (eds) The Routledge Companion to Criminological Theory and Concepts, pp. 415-418. Routledge, Abingdon.

van Wingerde CG (2015) The Limits of Environmental Regulation in a Globalized Economy: Lessons from the Probo Koala Case. In: van Erp J, Huisman W, Vande Walle G (eds) The Routledge Handbook of White-Collar and Corporate Crime in Europe, pp. 260-275. Abingdon, Routledge.

van Wingerde CG (2016) Deterring Corporate Environmental Crime: Lessons from the Waste Industry in the Netherlands. In: Spapens T, White R, Huisman W (eds) Environmental Crime in Transnational Context, pp. 193-207. Routledge, Abingdon.

Veljanovski C (2010) Economic Approaches to Regulation. In: Baldwin R, Cave M, Lodge M (eds) The Oxford Handbook of Regulation, pp. 17-38. OUP, Oxford.

Ward T, Green P (2016) Law, the State, and the Dialectics of State Crime. Critical Criminology 24, 217-230.

Weisburd D, Wheeler S, Waring E, Bode N (1991) Crimes of the Middle Classes. Yale University Press, New Haven, CT.

White R (2011) Transnational Environmental Crime: Toward an Eco-global Criminology. Routledge, London.

Whyte D (2014) Regimes of Permission and State-Corporate Crime. State Crime Journal 3, 237-246.

Wilks S (2013) The Political Power of the Business Corporation. Edward Elgar, Cheltenham, UK.

Williams JW (2008) The Lessons of "Enron": Media Accounts, Corporate Crimes, and Financial Markets. Theoretical Criminology 12, 471-499.

Wright JP, Cullen FT, Blankenship MB (1995) The Social Construction of Corporate Violence: Media Coverage of the Imperial Food Products Fire. Crime \& Delinquency 41, 20-36.

Young J (2012) Bernie Madoff, Finance Capital, and the Anomic Society. In: Will S, Handelman S, Brotherton D (eds) How They Got Away With It: White-collar Criminals and the Financial Meltdown, pp. 68-82. Columbia University Press, New York.

Zaitch D, Gutiírrez Gómez L (2015) Mining as State-corporate Crime: The Case of AngloGold. In: Barak G (ed) The Routledge International Handbook of the Crimes of the Powerful, pp. 386-398. Routledge, London.

\section{Laws cited}

Racketeer Influenced and Corrupt Organizations Act of 1970, 84 Stat. 922-3.

Organisation for Economic Co-operation and Development (OECD) Convention on Combating Bribery of Foreign Public Officials in International Business Transactions, (1997). Paris: OECD. 